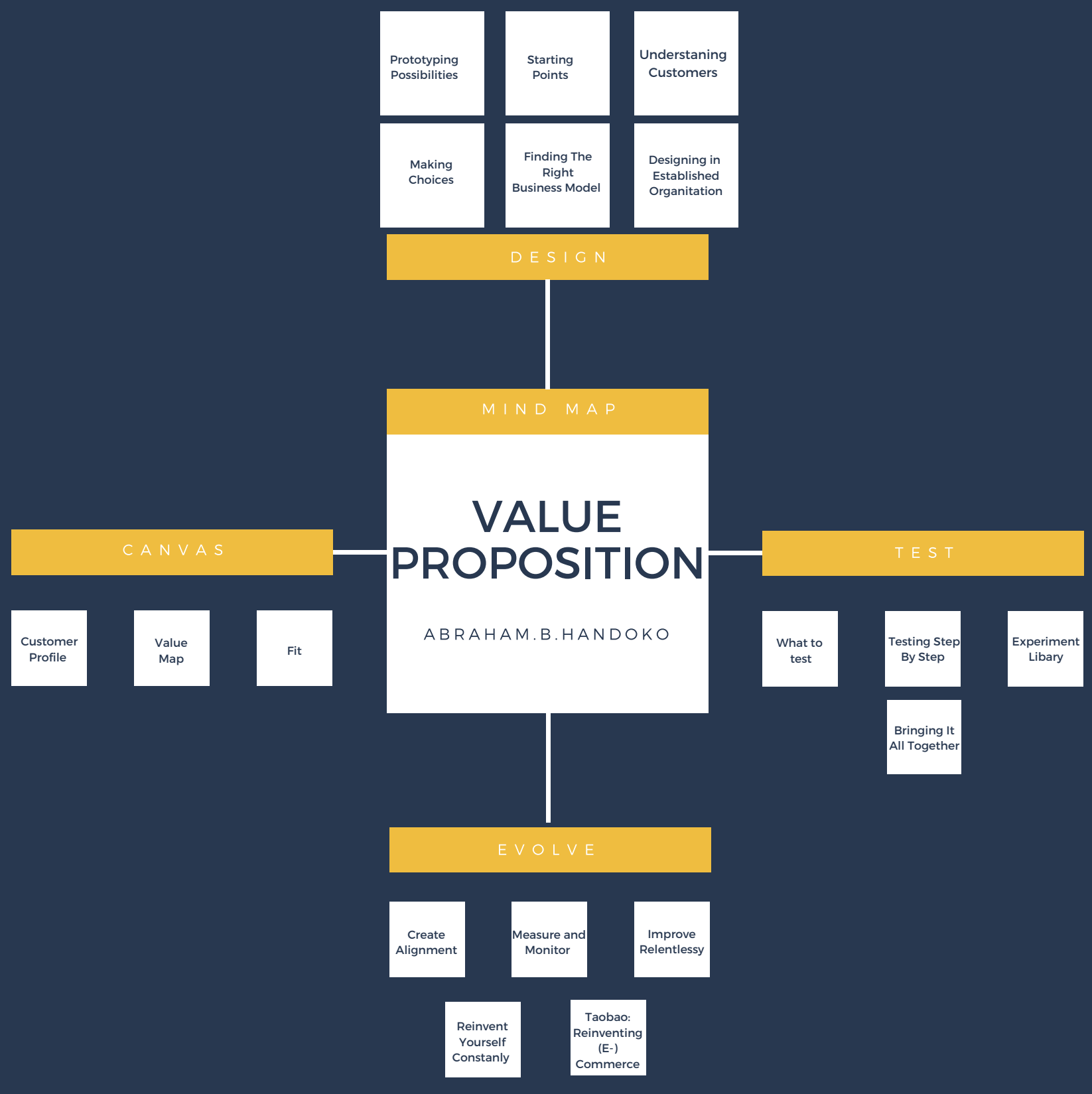

\section{MIND MAP VALUE PROPOSITION}

\begin{abstract}
ABRAHAM BASKARA HANDOKO 2440014736

UNIVERSITAS BINA NUSANTARA abraham.handoko@binus.ac.id
\end{abstract}

Referensi : ( Alexander Osterwalder, Yves Pigneur, Greg Bernada \& Alan Smith ( 2014 ) Value Proposition Design, John Wiley \& Sons, Inc )

Dosen Pembimbing : Agung Purnomo 